CZASOPISMO INŻYNIERII LĄDOWEJ, ŚRODOWISKA I ARCHITEKTURY JOURNAL OF CIVIL ENGINEERING, ENVIRONMENT AND ARCHITECTURE

JCEEA, t. XXXIII, z. 63 (2/II/16), kwiecień-czerwiec 2016, s. 351-358

Kamil Błażej POCHWAT ${ }^{1}$

\title{
WPŁYW WSPÓŁCZYNNIKA REDUKCJI PRZEPŁYWU ŚCIEKÓW $\beta$ NA DOBÓR GEOMETRII JEDNOKOMOROWEGO ZBIORNIKA RETENCYJNEGO
}

\begin{abstract}
W publikacji przedstawiono wyniki badań wpływu współczynnika redukcji przepływu ścieków przez zbiornik $\beta$ na dobór geometrii zbiornika retencyjnego, a w szczególności maksymalnego projektowego napełnienia ściekami. Za przedmiot badań przyjęto klasyczny jednokomorowy zbiornik retencyjny, w którym zamierzonym zmianom podlegało maksymalne projektowe napełnienie ścieków w zakresie od 0,8 do 3,0 m. Wyniki badań pozwoliły na wskazanie warunków, w których można ograniczyć niezbędną pojemność retencyjną zbiornika poprzez odpowiednie zaprojektowanie geometrii jego komory akumulacyjnej. Wyniki badań mogą przyczynić się do ograniczenia kosztów wykonania zbiorników retencyjnych. Przedstawione badania wykonano z wykorzystaniem programu do modelowania hydrodynamicznego Storm Water Management Model 5.0, przy obciążaniu zlewni rzeczywistymi danymi opadowymi.
\end{abstract}

Słowa kluczowe: zbiorniki retencyjne, modelowanie hydrodynamiczne, opady deszczu, maksymalne projektowe napełnienie w zbiorniku

\section{Wprowadzenie}

Wymagania stawiane obecnie sieciom kanalizacyjnym transportującym ścieki opadowe wymuszają coraz częściej stosowanie obiektów retencyjnych [1,2], które regulują przepływ ścieków w okresach wystąpienia opadu [3]. Stosowane są one na wszystkich etapach transportu i utylizacji ścieków [4], pozwalając w zależności od stosowanego systemu kanalizacyjnego m.in. na:

- odciążenie hydrauliczne sieci kanalizacyjnej,

- zabezpieczenie odbiornika przed nagłym zrzutem dużej ilości zanieczyszczonych ścieków,

- uśrednienie natężenia dopływu ścieków do oczyszczalni ścieków.

1 Kamil Błażej Pochwat, Politechnika Rzeszowska, Zakład Infrastruktury i Ekorozwoju, al. Powstańców Warszawy 6, 35-959 Rzeszów; tel.: 177432409; kp@ prz.edu.pl 
Największą grupę zbiorników stanowią te, które są stosowane do regulowania przepływu ścieków opadowych w sieciach kanalizacji deszczowej [5], wśród których istotną część stanowią zbiorniki realizowane w układzie jednokomorowym [6]. Jednym z najważniejszych parametrów hydraulicznych tego typu obiektów jest współczynnik redukcji przepływu ścieków $\beta$ [7]. Wielkość ta niesie w sobie informację o stopniu ograniczenia natężenia odpływu ścieków ze zbiornika $\mathrm{w}$ warunkach pełnego napełnienia $\mathrm{w}$ zbiorniku i maksymalnego natężenia dopływu ścieków do niego [8] (rys. 1.).

Dopływ

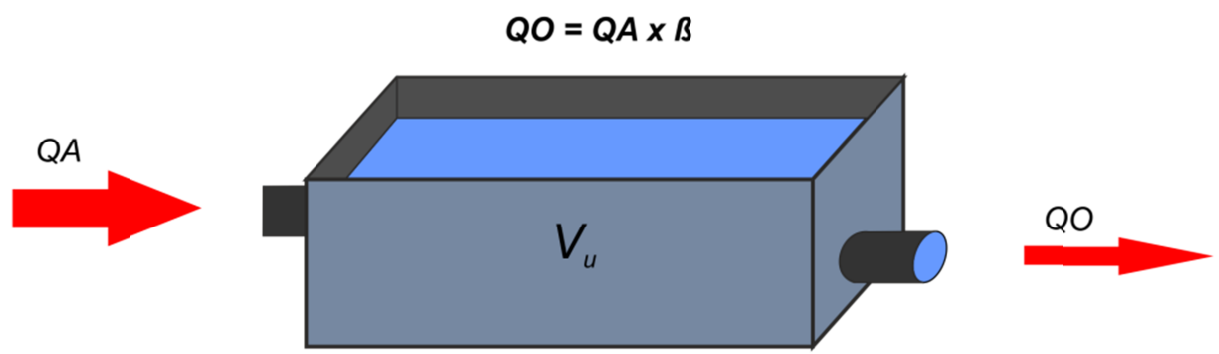

Rys. 1. Współczynnik redukcji przepływu ścieków $\beta$

Fig. 1. Flow reduction coefficient $\beta$

Z punktu widzenia możliwości realizacji inwestycji, obok warunków technicznych najistotniejszą rolę pełni czynnik ekonomiczny [9]. Jego racjonalizacja pozwala $\mathrm{w}$ wielu przypadkach na podejmowanie pozytywnych decyzji o realizacji inwestycji.

Ze względu na swoje gabaryty i konstrukcję, nakłady inwestycyjne ponoszone na budowę zbiorników są wysokie i zależą zasadniczo od ich pojemności, która z kolei uwarunkowana jest hydraulicznie. W konsekwencji tego priorytetem jest potrzeba dążenia do takiego kształtowania układów hydraulicznych zbiorników, które pozwoli na minimalizację ich niezbędnej pojemności retencyjnych przy zapewnieniu tego samego poziomu bezpieczeństwa hydraulicznego ich funkcjonowania.

Taki stan rzeczy można osiągnąć poprzez dobór odpowiednich parametrów projektowych [10], przy czym szczególne znaczenie posiada tutaj maksymalne projektowe napełnienie ścieków w zbiorniku $h_{s}$. Zależność ta została zauważona w pracach $[11,12,8]$, w których potwierdzono, że wraz ze zwiększaniem maksymalnego projektowego napełnienia ścieków w zbiorniku zmniejsza się jego niezbędna pojemność retencyjna $V_{u}$. 


\section{Cel badań}

Celem przeprowadzonych badań było potwierdzenie tezy, że istnieją takie zakresy wartości współczynnika redukcji przepływu ścieków $\beta \mathrm{w}$ zbiorniku retencyjnym, w których zwiększanie projektowego napełnienie ścieków w zbiorniku $h_{s}$ ma niewielki wpływ na redukcję niezbędnej pojemności retencyjnej $V_{u}$ oraz takie, w których zwiększanie projektowego napełnienia ścieków w zbiorniku ma bardzo istotny wpływ na zmniejszenie niezbędnej pojemności retencyjnej $V_{u}$.

\section{Przypadek studyjny i metodyka badań}

Zaplanowane analizy wykonano $\mathrm{z}$ wykorzystaniem oprogramowania do modelowania hydrodynamicznego SWMM 5.0. Jako obiekt badań przyjęty został zbiornik jednokomorowy, charakteryzujący się współczynnikami redukcji przepływu ścieków $\beta$ o wartościach od 0,1 do 0,7 i maksymalnym projektowym napełnieniem $h_{s}$, które podlegało celowym zmianom w zakresie wartości od 0,8 do $3,0 \mathrm{~m}$.

Podstawę analiz stanowiły zlewnie o powierzchniach zredukowanych równych 5 ha każda i różnych wartościach parametrów hydraulicznych charakteryzujących zlewnię i sieć kanalizacyjną [13]. Wyniki analiz sprawdzono także dla dwóch dodatkowych układów parametrów hydraulicznych zlewni i systemu kanalizacyjnego o powierzchniach zlewni równych 15 i 80 ha.

\section{Wyniki analiz}

Z przeprowadzonych badań wynika, że dla każdej wartości współczynnika redukcji przepływu ścieków $\beta$ zmniejszanie maksymalnego projektowego napełnienia ścieków w zbiorniku $h_{s}$, które wynikało ze zwiększenia powierzchni komory akumulacyjnej zbiornika $A_{l}$ powodowało zwiększenie niezbędnej pojemności retencyjnej zbiornika $V_{u}$ (rys.2), co potwierdziło wcześniejsze spostrzeżenia $[11,8]$.

Dodatkowo uzyskane wyniki badań wskazują, że w zależności od wartości współczynnika redukcji przepływu ścieków $\beta$ występowała różna siła wpływu maksymalnego projektowego napełnienia ścieków w zbiorniku $h_{s}$ na niezbędną pojemność retencyjną zbiornika $V_{u}$. Zostało to zaobserwowane poprzez analizę różnicy pojemności obliczonej przy napełnieniu ścieków 3,0 $\mathrm{m}\left(V u_{\text {min }}\right)$ oraz przy napełnieniu $0,8 \mathrm{~m}\left(V u_{\max }\right)$ (rys. 3.). 


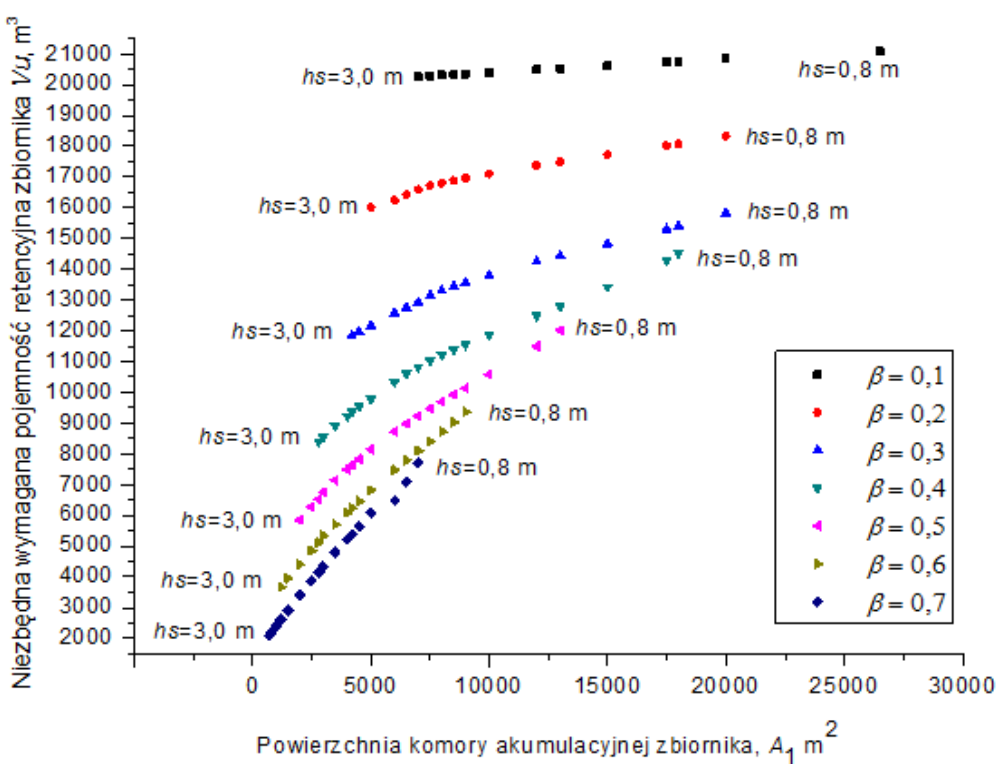

Rys. 2. Zależność pomiędzy powierzchnią komory retencyjnej $A_{I}$ zbiornika jednokomorowego a jego wymaganą pojemnością retencyjną $V u$ dla zlewni o powierzchni 80 ha

Fig. 2. Dependence between area of the reservoir and its required capacity $V_{u}$ for catchment with area equal 80 ha

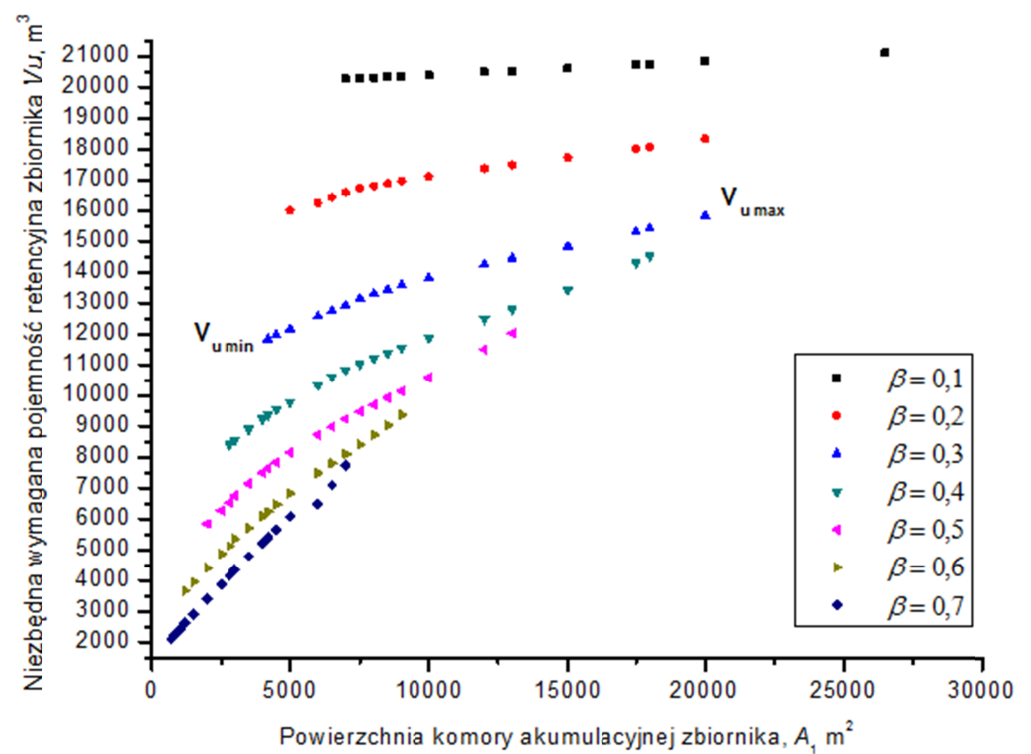

Rys. 3. Minimalna $\left(V u_{\min }\right)$ i maksymalna $\left(V u_{\max }\right)$ kubatura obiektu retencyjnego o określonej wartości współczynnika $\beta$

Fig. 3. Minimal $\left(V u_{\min }\right)$ and maximal $\left(V u_{\min }\right)$ capacity of storage reservoirs for different value of coefficient $\beta$ 
W celu oceny uzyskanej zależności wprowadzono wskaźnik $\eta$ wyrażony równaniem (1), który opisuje różnicę pomiędzy niezbędną pojemnością retencyjną zbiornika wyznaczoną dla napełnienia $0,8 \mathrm{~m}$ i napełnienia $3,0 \mathrm{~m}$.

$$
\eta=\frac{V_{u \max }}{V_{u \min }}
$$

gdzie: $V_{\text {umax }}$ - niezbędna pojemność retencyjna zbiornika wyznaczona dla napełnienia $h s$ równego $0,8 \mathrm{~m}, \mathrm{~m}^{3}$;

$V_{\text {umin }}$ - niezbędna pojemność retencyjna zbiornika wyznaczona dla napełnienia $h s$ równego $3,0 \mathrm{~m}, \mathrm{~m}^{3}$.

Kolejnym etapem analizy było przedstawienie uzyskanych wyników wskaźnika $\eta$ dla szesnastu badanych układów zlewni o powierzchni 5 ha każdy charakteryzujących się odmiennymi parametrami hydraulicznymi. Wyniki przedstawiono $\mathrm{w}$ tabeli 1 , gdzie zestawiono minimalną, maksymalną i średnią wartość współczynnika $\eta$.

Tabela 1. Minimalna, średnia i maksymalna wartość wskaźnika $\eta$ dla zlewni o powierzchni 5 ha Table 1. Minimal, average and maximal value of coefficient $\eta$ for catchment with area 5 ha

\begin{tabular}{|c|c|c|c|}
\hline $\begin{array}{c}\text { Współczynnik } \\
\text { redukcji przepływu } \\
\text { ścieków } \boldsymbol{\beta}\end{array}$ & $\begin{array}{c}\text { Średnia wartość } \\
\text { wskaźnika } \boldsymbol{\eta} \\
\text { (z 16 badanych } \\
\text { układów zlewni) }\end{array}$ & $\begin{array}{c}\text { Minimalna } \\
\text { wartość } \\
\text { wskaźnika } \boldsymbol{\eta}\end{array}$ & $\begin{array}{c}\text { Maksymalna } \\
\text { wartość } \\
\text { wskaźnika } \boldsymbol{\eta}\end{array}$ \\
\hline 0,1 & $\mathbf{1 , 0 9}$ & 1,06 & 1,16 \\
\hline 0,2 & $\mathbf{1 , 1 6}$ & 1,12 & 1,20 \\
\hline 0,3 & $\mathbf{1 , 2 0}$ & 1,17 & 1,25 \\
\hline 0,4 & $\mathbf{1 , 2 7}$ & 1,23 & 1,34 \\
\hline 0,5 & $\mathbf{1 , 3 7}$ & 1,32 & 1,49 \\
\hline 0,6 & $\mathbf{1 , 5 4}$ & 1,43 & 1,75 \\
\hline 0,7 & $\mathbf{1 , 8 1}$ & 1,60 & 2,06 \\
\hline
\end{tabular}

Z uzyskanych wyników badań jednoznacznie wynika, że wskaźnik $\eta$ rośnie wraz ze wzrostem współczynnika redukcji przepływ ścieków $\beta$. Zatem wpływ maksymalnego projektowego napełnienia ścieków w zbiorniku na niezbędną pojemność retencyjną jest tym większy im większą wartością współczynnika redukcji przepływu ścieków $\beta$ charakteryzuje się dany obiekt.

Analizując średnie wartości wskaźnika $\eta$ można zauważyć, że dla wartości współczynnika redukcji przepływu ścieków $\beta$ od 0,1 do 0,3 zmiana analizowanego napełnienia ścieków z maksymalnego $(3,0 \mathrm{~m})$ do minimalnego $(0,8 \mathrm{~m})$ powoduje wzrost niezbędnej pojemności retencyjnej $V_{u}$ (w zależności od $\beta$ ) w zakresie od 9 do 20\% (tab. 1). Natomiast dla większych wartości współczyn- 
nika redukcji przepływu ścieków $\beta$ od 0,4 do 0,7 zmiana tych wartości może powodować wzrost niezbędnej pojemności retencyjnej $V_{u}$ nawet o $81 \%$ (tab. 1).

Potwierdza to postawioną w pracy tezę, że można wyznaczyć zakres wartości współczynnika redukcji przepływu ścieków $\beta$, dla którego zwiększanie projektowego napełnienia ścieków w zbiorniku $h_{s}$ ma niewielki wpływ na redukcję niezbędnej pojemności retencyjnej zbiornika $V_{u}$ oraz takiego, dla którego zwiększanie napełnienia ścieków $h_{s}$ ma bardzo istotny wpływ.

Dalszym krokiem badań było potwierdzenie wyciągniętego wniosku dla innych powierzchni zlewni. W tym celu dokonano zestawienia wyników dla zlewni o powierzchni 5 ha, 15 ha i 80 ha. Wyniki obliczeń wartości wskaźnika $\eta$ dla zlewni o powierzchni 5 ha przyjęto, jako wartość średnią z szesnastu poddanych analizie układów zlewni. Uzyskane wyniki przedstawiono na rysunku 4.

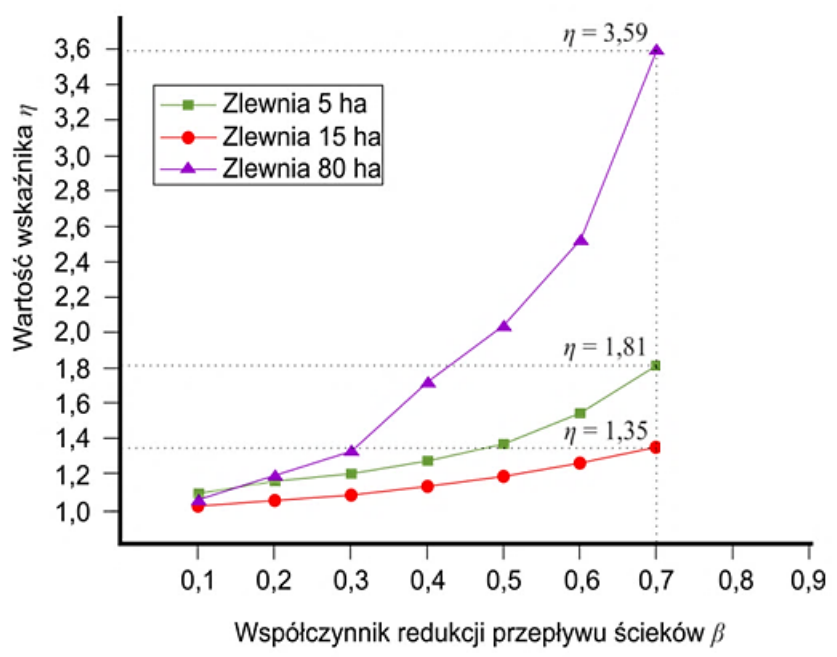

Rys. 4. Zależność wskaźnika $\eta$ od współczynnika redukcji przepływu $\beta$

Fig. 4. Dependence of indicator $\eta$ from coefficient $\beta$

Rozpatrując cały zakres analizowanych współczynników redukcji przepływu ścieków $\beta$ (od 0,1 do 0,7), w każdej z badanych zlewni zauważa się, dodatni wpływ współczynnika redukcji przepływu ścieków $\beta$ na wartość wskaźnika $\eta$. Wskazuje to na powiększenie się różnicy pomiędzy pojemnościami zbiorników wyznaczonymi dla napełnienia $3,0 \mathrm{~m}$ i napełnienia $0,8 \mathrm{~m}$.

\section{Podsumowanie}

Przeprowadzone badania pozwoliły na potwierdzenie postawionej $\mathrm{w}$ pracy tezy i sformułowanie istotnych wniosków z punktu widzenia metodologii projektowania zbiorników retencyjnych, które będą wykorzystywane na dalszym etapie badań geometrii zbiorników retencyjnych. 
- Istnieje możliwości wyznaczenia zakresów wartości parametrów współczynnika redukcji przepływu ścieków $\beta$, dla których zwiększanie projektowego napełnienia ścieków w zbiorniku $h_{s}$ ma niewielki wpływ na redukcję niezbędnej pojemności retencyjnej zbiornika $V_{u}$.

- Istnieje istotna zależność pomiędzy niezbędną pojemnością retencyjną zbiornika $V_{u}$ a maksymalnym projektowym napełnieniem ścieków w zbiorniku $h_{s}$, która zmienia się w zależności od wartości współczynnika redukcji przepływu ścieków $\beta$.

- Wpływ maksymalnego projektowego napełnienia ścieków w zbiorniku $h_{s}$ na jego niezbędną pojemność retencyjną $V_{u}$ jest tym większy im większym współczynnikiem redukcji przepływu ścieków $\beta$ charakteryzuje się obiekt retencyjny.

Podsumowując, ze względu na gabaryty i konstrukcje obiektów kubaturowych nakłady inwestycyjne ponoszone na ich budowę są wysokie, dlatego należy dążyć do minimalizacji ich niezbędnej pojemności $V_{u}$. Można to osiągnąć przez odpowiednie dostosowanie układu hydraulicznego zbiornika retencyjnego do warunków jego funkcjonowania. Dodatkowo należy stwierdzić, że dla zbiorników klasycznych charakteryzujących się niską wartością współczynnika $\beta$, projektowe maksymalne napełnienie ścieków $h_{s}$ nie ma istotnego wpływu na niezbędną pojemność retencyjną zbiornika $V_{u}$. Natomiast w przypadku zbiorników o większych wartościach współczynnika redukcji przepływu ścieków $\beta$, projektowe napełnienie ścieków $h_{s}$ w znacznym stopniu rzutuje na jego wymaganą pojemność retencyjną $V_{u}$. Uzyskane wyniki badań wskazują na konieczność wykonywania na etapie projektowym dogłębnej analizy i opracowania kilku wariantów rozwiązań ukształtowania komory akumulacyjnej klasycznego zbiornika retencyjnego, szczególnie tego, który charakteryzuje się wysokimi wartościami współczynnika redukcji przepływu ścieków $\beta$.

\section{Literatura}

[1] Calabro P.S., Viviani G.: Simulation of the operation of detention tanks, 2006.

[2] Nicholas D.I.: On-site stormwater detention: improved implementation techniques for runoff quantity and quality management in Sydney, Water Science and Technology, 32, 1995, pp. 85-91.

[3] Kordana S., Słyś D.: Analiza kosztów cyklu życia skrzynek rozsączających, Czasopismo Inżynierii Lądowej, Środowiska i Architektury JCEEA, z. 61 (3/I), 2014, s. $127-139$.

[4] Słyś D.: Zrównoważone systemy odwodnienia miast, Dolnośląskie Wydawnictwo Edukacyjne, Wrocław 2014.

[5] Kisiel A., Malmur R., Mrowiec M.: Retencyjne zbiorniki jako elementy nowoczesnych rozwiązań sieci kanalizacyjnych, Czasopismo Techniczne, 2008, s. 42-63.

[6] Phillips D.I.: A generic method of design of on-site stormwater detention storages, Water, Science and Technology, 1995, s. 93-99. 
[7] Szeląg B., Kiczko A.: The graphic method of sizing pipe reservoir for short, highintensity rainfalls, Annals of Warsaw university of Life Sciences - SGGW, Land Reclamation, 2014, pp. 221-232.

[8] Dziopak J.: Analiza teoretyczna i modelowania wielokomorowych zbiorników kanalizacyjnych, 1992.

[9] Czarniecki D., Słyś D.: Analiza techniczna i finansowa wariantów ogrzewania wody z wykorzystaniem pomp ciepła współpracujących z systemami rozsączania wody deszczowej w produkcji roślinnej, Czasopismo Inżynierii Lądowej, Środowiska i Architektury JCEEA, z. 61 (3/I), 2014, s. 33-51.

[10] Mrowiec M., Kisiel A.: Tubular storage tanks with internal throttle pipe for using in densely urbanized areas, Novatech, 2007, pp. 1267-1274.

[11] Słyś D.: Modelowanie wielokomorowych zbiorników grawitacyjno-pompowych. Kraków: Akademia Górniczo-Hutnicza w Krakowie, Wydział Geodezji Górniczej i Inżynierii Środowiska, 2004.

[12] Dziopak J., Starzec M.: Wpływ kierunku i prędkości przemieszczania się opadu deszczu na maksymalne szczytowe przepływy ścieków w sieci kanalizacyjnej, Czasopismo Inżynierii Lądowej, Środowiska i Architektury JCEEA, z. 61 (3/I), 2014, s. 63-81.

[13] Pochwat K.: Retencja zbiornikowa w małych zlewniach miejskich, Rzeszów 2015.

\section{THE INFLUENCE OF FLOW REDUCTION COEFFICIENT $\beta$ AT SELECTION OF GEOMETRY OF SINGLE-CHAMBER STORAGE RESERVOIR}

\section{S u m m a r y}

The paper presents the results of the impact of the flow reduction coefficient through the reservoir $\beta$ at the selection of the geometry of the reservoir, Particular the maximum design fill in storage reservoir. By the object of research assumed a classical single-chamber reservoir in Which were changed the maximum design fill, in the range of 0.8 to $3.0 \mathrm{~m}$. Obtained results allowed for Identifying a conditions in which it is possible to minimizing the necessary capacity of the storage reservoir. Results can be used for reduce the costs of building of storage reservoirs. The analysis was Performed using the program for hydrodynamic modeling of sewerage systems (Storm Water Management Model 5.0), with the loading of the catchment real rainfall date.

Keywords: storage reservoirs, hydrodynamic modeling, rainfall, the maximum design fill in the storage

DOI: $10.7862 / \mathrm{rb} .2016 .170$

Przestano do redakcji: 01.05.2016 $r$.

Przyjęto do druku: 28.06.2016 r. 